\title{
PEMBELAJARAN MATEMATIKA MELALUI MODEL KONSTRUKTIVISME TIPE NOVICK UNTUK MENINGKATKAN KEMAMPUAN PENALARAN MATEMATIS SISWA SMP
}

\author{
Taufiq $^{(1)}$, Junaidi ${ }^{(2)}$ \\ Program Studi Pendidikan Matematika FKIP Universitas Jabal Ghafur Sigli
}

\begin{abstract}
ABSTRAK
Penelitian ini bertujuan mendeskripsikan pembelajaran matematika melalui model konstruktivisme tipe novick dapat meningkatkan kemampuan penalaran matematis siswa pada SMP Negeri 2 Sakti. Populasi penelitian ini adalah siswa kelas VIII SMPN 2 Sakti Kabupaten Pidie sekitar 86 siswa. Penentuan sampel dilakukan secara random sampling sehingga terpilih sebanyak dua kelas yang berjumlah 44 siswa. Metode penelitian pada penelitian ini merupakan penelitian kuasi eksperimen dan menggunakan analisis perbedaan. Pengumpulan data dilakukan dengan teknik tes dan pengolahan data menggunakan statistik dengan menggunakan uji-t. Hasil pengolahan data menunjukkan bahwa pembelajaran matematika melalui model konstruktivsme tipe novick dapat meningkatkan kemampuan penalaran matematis siswa SMP Negeri 2 Sakti pada materi pola bilangan. Berdasarkan hasil analisis data dapat disimpulkan bahwa peningkatan kemampuan penalaran matematis siswa yang mendapat model konstruktivisme tipe novick lebih baik daripada siswa yang mendapatkan pembelajaran konvensional.
\end{abstract}

Kata Kunci: Model Konstruktivisme Tipe Novick, Kemampuan Penalaran Matematis.

\section{Pendahuluan}

Salah satu ilmu yang sangat penting dalam kehidupan manusia adalah matematika. Matematika mempunyai peranan yang sangat penting dalam kehidupan manusia, hampir setiap aktivitas manusia melibatkan matematika, oleh karena itu setiap orang diharapkan dapat menguasai matematika agar mampu dalam menyelesaikan masalah yang dihadapi dan menghadapi tantangan masa depan dalam persaingan global dimana ilmu pengetahuan dan teknologi berkembang pesat.

Walaupun matematika merupakan salah satu mata pelajaran yang penting, kebanyakan siswa tidak menyukai matematika. Banyak siswa menganggap matematika sangat sulit dipelajari, tidak menyenangkan dan membosankan. Apabila anggapan tersebut sudah tertanam dalam pikiran siswa maka siswa akan mengalami kesulitan dalam mempelajari bahkan untuk meningkatkan kemampuan penalaran matematika. Kemampuan penalaran matematika merupakan kemampuan dasar yang harus dikuasai oleh siswa, karena sebelum siswa mempelajari materi yang baru, siswa terlebih dahulu harus memahami materi sebelumnya. Materi dalam pelajaran matematika mempunyai keterkaitan dengan materi-materi yang sudah dipelajari.

Dari pengamatan yang dilakukan selama 2 bulan di SMP Negeri 2 Sakti terlihat pemahaman siswa akan suatu konsep matematika masih relatif rendah. Pada pokok bahasan barisan bilangan kebanyakan siswa terutama kelas VIII, kurang memahami unsur-unsur barisan bilangan yang dipelajari pada awal pembelajaran.

Berdasarkan wawancara dengan salah satu guru matematika di SMP Negeri 2 Sakti, bahwa kesulitan guru dalam mengajar adalah jumlah siswa yang banyak sekitar 25 siswa dalam satu kelas dengan waktu yang relatif sedikit, sedangkan materi yang harus di ajarkan tidak sebanding dengan waktu yang tersedia. Sehingga sebagian besar siswa kurang paham dengan konsep materi yang di ajarkan oleh guru. Kemampuan penalaran matematika yang rendah dapat berpengaruh pada hasil belajar siswa, seperti 
hasil belajar di kelas VIIIA SMP Negeri 2 Sakti Kabupaten Pidie. Hanya 26,32\% siswa yang mencapai KKM (70), dan 36,84\% siswa yang mendapat nilai diatas rata-rata.

Faktor lain selain masalah waktu yang menyebabkan rendahnya kemampuan penalaran siswa terhadap matematika adalah cara mengajar guru yang masih berpusat pada guru (teacher center). Dalam hal ini siswa tidak berperan besar dalam proses pembelajaran yang berpusat pada guru, sehingga mengakibatkan siswa menjadi pasif dan motivasi untuk belajar rendah. Selain itu guru sering memberi latihan soal setelah menjelaskan materi, akan tetapi pada saat proses pembelajaran berlangsung tidak terlalu menguatkan konsep siswa, sehingga ketika mengerjakan soal siswa banyak melakukan kesalahan, padahal ketika proses pembelajaran siswa banyak yang sudah paham dengan materi yang diajarkan. Sebagian besar siswa menghafal rumus yang diberikan oleh guru, tanpa memahami bagaimana proses rumus tersebut terbentuk. Seharusnya dalam kegiatan pembelajaran siswa tidak hanya menerima pengetahuan tetapi siswa harus mampu mengaplikasikan pengetahuan yang dimilikinya dalam kehidupan sehari-hari, dan untuk mengaplikasikan pengetahuan yang dimilikinya, siswa harus terlebih dahulu memahami apa yang dipelajarinya. Proses yang harus dilakukan siswa sebelum memahami yaitu mengenal terlebih dahulu materi tersebut, misalnya tentang barisan bilangan, siswa terlebih dahulu harus mengetahui pengertian barisan bilangan, dan perbedaan antara barisan dan bilangan. Berdasarkankenyataan diatas guru sebaiknya menggunakan suatu model pembelajaran yamg dapat meningkatkan kemampuan penalaran siswa. Peneliti tertarik menggunakan model pembelajaran konstruktivisme tipe Novick untuk meningkatkan kemampuan penalaran siswa.

Pengertian konstruktivisme tipe novick adalah proses membangun atau menyusun pengetahuan baru dalam struktur kognitif siswa berdasarkan pengalaman". Pengetahuan seseorang dapat dibentuk dari pengalamannya sehari-hari, baik itu di lingkungan sekolah atau di luar sekolah (Sanjaya, 2011:118).

Konstruktivisme tipe novick adalah suatu pendekatan terhadap belajar yang berkeyakinan bahwa orang secara aktif membangun atau membuat pengetahuannya sendiri dan realitas ditentukan oleh pengalaman orang itu sendiri pula (Abimanyu, 2008: 22).

Pembelajaran yang berciri konstruktivisme tipe novick menekankan terbangunnya pemahaman sendiri secara aktif, kreatif dan produktif berdasarkan pengetahuan terdahulu dan pengalaman belajar yang bermakna (Muslich, 2007:44).

Konstruktivisme tipe novick adalah sebuah teori yang memberikan kebebasan terhadap manusia yang ingin belajar atau mencari kebutuhannya dengan kemampuan untuk menemukan keinginan atau kebutuhannya tersebut dengan bantuan fasilitas orang lain. Manusia untuk belajar menemukan sendiri kompetensi, pengetahuan atau teknologi dan hal yang diperlukan guna mengembangkan dirinya (Thobroni, 2015:91). Konstruktivisme tipe novick merupakan landasan berfikir pendekatan kontekstual, pengetahuan dibangun sedikit demi sedikit untuk meningkatkan hasil, hasilnya diperluas melalui konteks yang terbatas (sempit) dan tidak dengan tiba-tiba (Sagala, 2007: 88).

Konstruktivisme novick memandang bahwa pengetahuan individu merupakan hasil dari proses membangun pengetahuan berdasarkan pengalaman dalam sistem kognisi individu. Dalam pembelajaran, konstruktivisme memandangnya sebagai suatu proses sosial (wacana) membangun pengetahuan (yang ilmiah) yang dipengaruhi oleh pengetahuan awal, pandangan dan keyakinan peserta didik serta pengaruh pendidik (Suratno, 2008:1).

Teori konstruktivis novick satu prinsip yang paling penting dalam psikologi pendidikan adalah bahwa guru tidak hanya sekedar memberikan pengetahuan kepada siswa. Siswa harus membangun sendiri pengetahuan didalam benaknya. Guru dapat 
memberikan kemudahan untuk proses ini, dengan memberi kesempatan siswa untuk menemukan atau menerapkan ide-ide mereka sendiri, mengajar siswa menjadi sadar dan secara sadar menggunakan strategi mereka sendiri untuk belajar (Trianto, 2007:14).

Model pembelajaran novick merupakan model pembelajaran yang merujuk pada pandangan konstruktivisme. Gagasan utama dari model pembelajaran ini adalah proses perubahan konseptual dari pengetahuan awal siswa pada proses pembelajaran. Proses perubahan konseptual terjadi melalui akomodasi kognitif dan pembelajaran untuk perubahan konseptual ini terutama melibatkan penggalian konsep awal siswa pada peristiwa tertentu dan penggunaan cara-cara untuk membantu para siswa mengubah konsep mereka yang kurang tepat sehingga mereka mendapat suatu konsep baru yang lebih ilmiah (Arkundato, 2007:15).

Tujuan dilaksanakan pembelajaran konstruktivisme yaitu (1) memberikan kesempatan kepada siswa untuk berinteraksi langsung kepada benda-benda konkrit ataupun model artifisial, (2) memperhatikan konsepsi awal siswa guna menanamkan konsep yang benar, dan (3) sebagai proses mengubah konsepsi-konsepsi siswa yang sudah ada dan mungkin salah (Karfi, 2002:6). Tujuan konstruktivisme tipe novick yaitu: 1) Mengembangkan kemampuan siswa untuk mengajukan pertanyaan dan mencari sendiri pertanyanya 2) Membantu siswa untuk mengembangkan pengertian dan pemahaman konsep secara lengkap 3) Mengembangkan kemampuan menjadi pemikir yang mandiri (Thobroni, 2015:95).

Hal yang sama dipaparkan oleh Hapsari (2010:17) bahwa berdasarkan paham konstruktivisme tipe novick, dalam proses belajar mengajar, guru tidak serta merta memindahkan pengetahuan kepada peserta didik dalam bentuk yang serba sempurna. Di sini peserta didik harus membangun suatu pengetahuan berdasarkan pengalamannya masing-masing. Pembelajaran adalah hasil dari usaha peserta didik itu sendiri. Siswa membangun pemahaman dan pengetahuan mereka melalui pengalaman dalam kehidupan sehari-hari. Oleh karena itu, ketika siswa menghadapi pengalaman yang baru, siswa harus menerimanya dengan ide sebelumnya dan pengalaman yang telah mereka dapat. Untuk itu, siswa harus membangun pikiran mereka menilai tentang apa yang mereka ketahui.

Trianto, (2007:5) mengemukan bahwa model pembelajaran adalah kerangka konseptual yang melukiskan prosedur yang sistematis dalam mengorganisasikan pengalaman belajar untuk mencapai tujuan belajar tertentu, dan berfungsi sebagai pedoman bagi para perancang pembelajaran dan para pengajar dalam merencanakan aktivitas belajar mengajar.

Model konstruktivisme tipe novick merupakan salah satu model pembelajaran yang merujuk pada pandangan konstruktivisme. Gagasan utama dari model ini adalah proses dari perubahan konseptual dari pengetahuan awal siswa pada proses pembelajaran. Berdasarkan uraian di atas maka untuk mencapai tujuan yang telah ditetapkan, baik dalam tujuan intruksional umum maupun tujuan intruksional khusus, diperlukan penggunaan metode yang tepat yang sesuai dengan materi yang akan diajarkan. Dalam menyampaikan materi pelajaran, seorang guru harus menggunakan metode yang tepat agar dapat meningkatkan motivasi siswa dalam mengikuti pembelajaran. Untuk itu seorang guru harus dapat memilih metode yang benar-benar sesuai dan mampu meningkatkan motivasi serta pemahaman siswa dalam mengikuti pelajaran dan menerima pelajaran. Pembelajaran pada hakekatnya adalah proses interaksi antara peserta didik dengan lingkungannya, sehingga terjadi perubahan perilaku kearah yang lebih baik. Dalam interaksi tersebut banyak sekali faktor yang mempengaruhinya, baik faktor internal yang datang dari dalam diri individu, maupun faktor eksternal yang datang dari lingkungan. 
Berdasarkan pengertian tersebut maka dapat dikatakan bahwa pengetahuan bukanlah seperangkat fakta-fakta, konsep, atau kaidah yang siap untuk diambil dan diingat. Tetapi manusia harus mengkonstruksi pengetahuan itu dan memberi makna melalui pengalaman nyata. Siswa perlu dibiasakan memecahkan masalah, menemukan sesuatu yang berguna bagi dirinya, dan bergelut dengan ide-ide, yaitu siswa harus mengkonstruksikan pengetahuan di benak mereka sendiri. Pengetahuan bukanlah serangkaian fakta, konsep serta kaidah yang siap dipraktikkan. Manusia harus mengkonstruksinya terlebih dahulu pengetahuan tersebut dan memberikan makna melalui pengalaman nyata. Karena itu siswa perlu dibiasakan untuk memecahkan masalah, menemukan sesuatu yang berguna bagi dirinya, dan mengembangkan ide-ide yang ada pada dirinya.

Tahapan-tahapan dalam pembelajaran dengan pendekatan konstruktivisme tipe novick, yaitu sebagai berikut:

Tahap pertama, peserta didik didorong agar mengemukakan pengetahuan awalnya tentang konsep yang akan dibahas. Bila perlu, guru memancing dengan pertanyaan problematik tentang fenomena yang sering dijumpai seharihari oleh peserta didik dan mengaitkannya dengan konsep yang akan dibahas. Selanjutnya, peserta didik diberi kesempatan untuk mengkomunikasikan dan mengilustrasikan pemhamannya tentang konsep tersebut.

Tahap kedua, peserta didik diberi kesempatan untuk menyelidiki dan menemukan konsep melalui pengumpulan, pengorganisasian, dan penginterprestasian data dalam suatu kegiatan yang telah dirancang oleh guru. Secara keseluruhan dalam hidup ini akan terpenuhi rasa keingintahuan peserta didik tentang fenomena dalam lingkungannya.

Tahap ketiga, peserta didik melakukan penjelasan dan solusi yang didasarkan pada hasil observasi peserta didik, ditambah dengan penguatan guru. Selanjutnya peserta didik membangun pemahaman baru tentang konsep yang sedang dipelajari.

Tahap keempat, guru berusaha menciptakan iklim pembelajaran yang memungkinkan peserta didik dapat mengaplikasikan pemahaman konseptualnya, baik melalui kegiatan maupun pemunculan masalahmasalah yang berkatian dengan isu-isu dalam lingkungan peserta didik tersebut (Lapono, 2008: 3-28).

Kemampuan berasal dari kata "mampu". Dalam kamus Besar Bahasa Indonesia mampu artinya kuasa (bisa, sanggup) melakukan sesuatu; dapat. Sedangkan kemampuan adalah suatu kesanggupan dalam melakukan sesuatu. Seseorang dikatakan mampu apabila ia bisa melakukan sesuatu yang harus ia lakukan.

Penalaran (reasoning) menurut ensiklopedia wikipedia adalah proses berpikir yang bertolak dari pengamatan indera (observasi empirik) yang menghasilkan sejumlah konsep dan pengertian. Menurut Sumedi dan Mustakin (Ma'sum, 2012:3) penalaran merupakan suatu kegiatan berpikir yang mempunyai karakteristik tertentu dalam menentukan kebenaran. Sedangkan menurut Marsigit (Setiadi, 2011:11) mengatakan bahwa penalaran merupakan proses berpikir dalam menarik kesimpulan yang berupa pengetahuan untuk memperoleh kebenaran. Agar pengetahuan yang dihasilkan penalaran itu mempunyai dasar kebenaran maka proses berpikir itu harus dilakukan dengan suatu cara tertentu sehingga penarikan kesimpulan baru tersebut dianggap sahih (valid).

$$
\text { Sudjadi (Ma'sum, }
$$
menyatakan terdapat beberapa ciri penalaran di antaranya:

Adanya suatu pola berpikir yang disebut logika. Dalam hal ini dapat dikatakan bahwa kegiatan penalaran merupakan suatu proses berpikir logis. Berpikir logis ini diartikan sebagai berpikir menurut suatu pola tertentu atau menurut logika tertentu;

Proses berpikirnya bersifat analisis. Penalaran merupakan suatu kegiatan yang mengandalkan diri pada suatu analisis, 
dalam kerangka berpikir yang dipergunakan untuk analisis tersebut adalah logika penalaran yang bersangkutan.

Menurut Setiadi, (2011:13) terdapat 8 elemen penalaran yaitu:

Tujuan (purpose) Penalaran harus memiliki tujuan. Untuk memahami beberapa hal, seseorang harus dapat mendefinisika tujuan dengan jelas apakah tujuannya membujuk, menginformasikan dan sebagainya.

Pertanyaan (question) Penalaran adalah usaha menjawab pertanyaan yang menjadi masalah, dapat dilakukan dengan cara menggambarkan sesuatu, menetapkan pertanyaan dan menyelesaikan masalah. Hal yang penting dalam mengidentifikasi pertanyaan-pertanyaan adalah untuk memahami tujuan.

Asumsi (assumption) Penalaran harus berdasarkan asumsi. Berpikir efektif mencoba mengidentifikasi asumsi dengan jelas dan menentukan apakah asumsi tersebut dapat dipertanggungjawabkan, serta bagaimana asumsi tersebut membentuk sudut pandang.

Sudut pandang (point of view) Penalaran dibuat dengan memperhatikan beragam sudut pandang dalam hal ini beragam alternatif penyelesaian.

Informasi (information) Penalaran berdasarkan informasi yaitu data dan fakta. Berpikir mencoba mengidentifikasi informasi, meyakinkan bahwa infromasi yang digunakan jelas, dan relevan dengan pertanyaan yang menjadi pokok masalah.

Konsep dan ide (concept and idea) Penalaran dinyatan dan dibentuk berdasarkan konsep dan ide yaitu definisi, teori, prinsip, aturan, dan model. Hal yang penting untuk mengidentifikasi konsep penting dan menjelaskan konsep tersebut dengan jelas.

Penyimpulan (inference) Penalaran terdiri dari penarikan kesimpulan atau interprestasi yang menggambarkan kesimpulan dan memberi pengertian dari data.

Implikasi (implication) Penalaran akan memiliki implikasi dan konsekuensi.
Suatu hal yang penting untuk menemukan implikasi dan konsekuensi dari suatu penalaran seseorang, mencari implikasi negatif dan positifnya, dan mempertimbangkan konsekuensikonsekuensi yang mungkin.

Lebih lanjut, Ma'sum, (2012:4) mendefinisikan bahwa penalaran merupakan suatu kegiatan, suatu proses atau suatu aktivitas berfikir untuk menarik kesimpulan atau membuat suatu pernyataan baru yang benar berdasar pada beberapa pernyataan yang kebenarannya telah dibuktikan atau diasumsikan sebelumnya.

Secara umum dikenal dua jenis penalaran, yakni penalaran induktif dan penalaran deduktif. Penalaran induktif merupakan suatu kegiatan, suatu proses atau suatu aktivitas berpikir untuk menarik kesimpulan atau membuat suatu pernyataan baru yang bersifat umum (general) berdasar pada beberapa pernyataan khusus yang diketahui benar. Dalam matematika penalaran deduktif lebih banyak digunakan dari pada penalaran induktif. Hal ini dikarenakan dalam pembelajaran matematika untuk menarik kesimpulan matematis harus didasarkan pada beberapa pernyataan yang telah diyakini kebenarannya yaitu berupa aksioma, definisi, atau teorema yang kebenarannya telah dibuktikan sebelumnya.

Kemampuan penalaran adalah kemampuan siswa untuk berpikir logika menurut alur kerangka berpikir tertentu. Kemampuan penalaran berarti kemampuan menarik konklusi atau kesimpulan yang tepat dari bukti-bukti yang ada dan menurut aturan-aturan tertentu.

Menurut Al Krismanto (Setiadi, 2011:13) di dalam mempelajari matematika kemampuan penalaran dapat dikembangkan pada saat peserta didik memahami suatu konsep (pengertian), atau menemukan dan membuktikan suatu prinsip.

Ada banyak cara mengembangkan kemampuan penalaran peserta didik, antara lain guru memacu peserta didik agar mampu berpikir logis dengan memberikan soal-soal penerapan sesuai dengan kehidupan sehari- 
hari yang kemudian diubah dalam bentuk matematika. Peserta didik sendiri juga dapat mengembangkan kemampuan penalaran dengan belajar menganalisa sesuatu berdasarkan langkah-langkah yang sesuai dengan teorema dan konsep matematika (Setiadi, 2011:13).

Berdasarkan uraian di atas, maka pengertian dari Kemampuan penalaran matematis merupakan suatu kemampuan berpikir menurut alur kerangka berpikir tertentu berdasarkan konsep atau pemahaman yang telah didapat sebelumnya untuk mendapatkan suatu keputusan baru yang logis dan dapat dipertanggung jawabkan dan dibuktikan kebenarannya.

Terdapat beberapa penelitian terdahulu yang pernah dilakukan yaitu Hasil penelitian Sumarni (2016) Menunjukkan bahwa siswa yang menerapkan Model Konstruktivisme Tipe Novick hasil belajar meningkatkan dari pada siswa belajar dengan menggunakan model pembelajaran konvesional.

Penelitian yang dilakukan oleh Bambang Riyanto (2015) dari hasil penelitian ini dapat dikemukakan simpulan sebagai berikut: Terdapat pengaruh kemampuan penalaran terhadap prestasi siswa, yaitu prestasi siswa yang kemampuan penalarannya tinggi lebih baik daripada siswa yang penalarannya rendah. Berdasarkan analisis anova dua jalur, tidak terdapat interaksi antara pendekatan pembelajaran dan kemampuan penalaran terhadap prestasi siswa. Hal ini berarti prestasi matematika siswa dengan pendekatan konstruktivisme lebih baik daripada dengan pendekatan konvensional untuk semua level atau tahap kemampuan penalaran siswa.

Penelitian yang dilakukan oleh Nur Chasanah (2015) hasil penelitian ini menunjukkan bahwa rata-rata data pretes kelas ekperimen 15,3 dan rata-rata postes kelas eksperimen 20,57. Sehingga untuk data pretes kelas kontrol diperoleh dengan rata-rata 13,89 dan rata-rata postes kelas kontrol adalah 14,7. Setelah dilakukan uji hipotesis dengan taraf signifikan 0,05 diperoleh bahwa ada peningkatan matematika melalui pendekatan konstruktivisme pada pokok bahasan bangun datar dengan melihat dari selisih nilai rata-rata kelas ekperimen sebesar 5,13 atau $18,32 \%$. Sedangkan peningkatan penalaran matematika untuk kelas kontrol sebesar 0,18 atau 2,89\%. Hal ini menunjukkan bahwa pembelajaran dengan pendekatan konstruktivisme dapat meningkatkan penalaran matematika.

\section{Metode}

Perlakuan dengan Metode penelitian yang digunakan adalah metode eksperimen semu (quasi experimental). Metode ini mempunyai kelompok kontrol, tetapi tidak dapat berfungsi sepenuhnya untuk mengontrol variabel-variabel luar yang mempengaruhi pelaksanaan eksperimen. Metode eksperimen dalam penelitian ini menggunakan jenis desain penelitian dengan metode pretest-postest control group design

Populasi target pada penelitian ini adalah seluruh siswa SMPN 2 Sakti Kabupaten Pidie. Populasi terjangkau pada penelitian ini adalah seluruh siswa SMPN 2 Sakti kelas VIII pada semester Ganjil tahun 2018/2019 yang terbagi dalam 3 kelas. Jumlah siswa kelas VIII SMPN 2 Sakti Kabupaten Pidie sekitar 86 siswa.

Adapun teknik pengambilan sampel menggunakan purposive sampling (peneliti menentukan pengambilan sampel dengan cara menetapkan ciri-ciri khusus). Adapun sampel penelitian ini adalah sebanyak dua kelas VIII. Kelas eksperimen dijarkan dengan metode konvensional dan kelas kontrol menggunakan model konstruktivisme tipe novick.

\section{Hasil Dan Pembahasan}

Berdasarkan hasil uji normalitas yang telah dilakukan sebelumnya didapat kesimpulan bahwa skor gain ternormalisasi kelas model konstruktivisme tipe novick dan kelas konvensional berdistribusi normal. Sedangkan untuk uji homogenitas menunjukkan bahwa varians skor gain ternormalisasi kemampuan penalaran 
matematis kedua kelompok homogen. Sehingga untuk membuktikan bahwa skor gain ternormalisasi kemampuan penalaran matematis siswa kelas model konstruktivisme tipe novick berbeda dengan kelas konvensional dilakukan uji perbedaan rataan skor gain ternormalisasi dengan menggunakan uji-t.

Tabel 1. Data Hasil Uji Perbedaan Rataan Skor Gain Ternormalisasi

\begin{tabular}{|c|l|l|l|}
\hline \multicolumn{3}{|c|}{ t-test for Equality of } & \multirow{2}{*}{ Kesimpulan } \\
\hline $\mathrm{t}$ & $\mathrm{f}$ & Sig. (2-tailed) & \\
\hline 8,263 & 2 & 0,000 & H0 Ditolak \\
& 2 & & \\
\hline
\end{tabular}

Tabel diatas diperoleh thitung $=8,263$ untuk $\alpha=0,05$ dengan $\mathrm{df}=42$, nilai ttabel $=2,02$, maka thitung berada di daerah penolakan $\mathrm{H} 0$, atau nilai signifikan $0,000<$ $\alpha=0,05$ sehingga $\mathrm{H} 0$ ditolak yang artinya terdapat perbedaan yang signifikan antara peningkatan kemampuan penalaran matematis siswa yang mendapat model konstruktivisme tipe novick. Dengan demikian peningkatan kemampuan kemampuan penalaran matematis siswa yang mendapat model konstruktivisme tipe novick lebih baik daripada siswa yang mendapatkan pembelajaran konvensional.

Berdasarkan kemampuan siswa pada kelompok eksperimen dalam membangun pengetahuan adalah cukup baik, hal ini menunjukkan bahwa dalam proses pembelajaran siswa sudah mengaktifkan pengetahuan yang sudah dimilikinya dalam rangka mengkonstruk pengetahuan baru. Pengetahuan awal sangat penting untuk membangun pengetahuan baru seperti yang dikemukakan oleh Ernest (2001: 84) bahwa pengetahuan awal (pengetahuan subjektif matematika) berperan dalam membuat atau mengkonstruksi pengatahuan baru (pengetahuan objektif matematika) melalui interaksi sosial, hal ini didukung juga oleh Sumarmo (2010:34) bahwa salah satu disposisi kuat dan prilaku cerdas adalah memanfaatkan pengalaman lama untuk membentuk pengetahuan baru, misalnya melakukan analogi dan berusaha mengaitkan pengalaman

Pembelajaran dikatakan efektif adalah ketika siswa dapat lebih berkembang dengan memanfaatkan informasi seperti melihat dibalik apa yang tertulis, sehingga siswa dapat menggunakan pengetahuan yang baru secara aktif untuk mengkonstruksi makna. Dalam penelitian ini, kemampuan siswa dalam mengilustrasikan pengetahuan awal adalah sangat baik, sehingga dengan pembelajaran konstruktivisme ini siswa akan baik dalam penguasaan konsep yang dipelajarinya. Dalam pembelajaran dengan pendekatan konstruktivisme terjadi interaksi dalam kelompok, yaitu pada tahap eksplorasi dan interaksi antar kelompok, yaitu pada tahap diskusi dan penjelasan konsep. Pada pembelajaran konstruktivisme ini, guru berperan sebagai fasilitator, moderator, dan membimbing siswa dalam proses mengkonstruksi pengetahuan baru.

\section{Simpulan}

Berdasarkan hasil penelitian yang dilaksanakan mengenai pembelajaran matematika dengan model pembelajaran konstruktivisme tipe Novick terhadap kemampuan penalaran matematis siswa di SMP Negeri 2 Sakti diperoleh beberapa kesimpulan sebagai berikut:

1. Pembelajaran matematika melalui model konstruktivsme tipe novick dapat meningkatkan kemampuan penalaran matematis siswa SMP Negeri 2 Sakti pada materi pola bilangan.

2. Berdasarkan hasil pengolahan data dengan taraf signifikan $\alpha=0,05$ dan derajat kebebasan $=42$ dan daftar distribusi $\mathrm{t}$ diperoleh $=2,02$ sedangkan $\mathrm{t}_{\text {hitung }}=8,263$ ini berarti $\mathrm{t}_{\text {hitung }} \geq \mathrm{t}_{\text {tabel }}$ atau nilai signifikan $0,000<\alpha=0,05$ sehingga $\mathrm{H}_{0}$ ditolak yang artinya terdapat perbedaan yang signifikan antara peningkatan kemampuan penalaran matematis siswa yang mendapat model konstruktivisme tipe novick. Dengan demikian peningkatan kemampuan 
kemampuan penalaran matematis siswa yang mendapat model konstruktivisme tipe novick lebih baik daripada siswa yang mendapatkan.

\section{Daftar Pustaka}

Abimanyu, Soli. dkk. 2008. Strategi Pembelajaran. Jakarta: Direktorat Jendral.

Arkundato. 2007. Pembaharuan dalam Pembelajaran Matematika. Jakarta : Universitas Terbuka

Bambang Riyanto. 2015. Pengaruh Penalaran terhadap Prestasi Siswa. Jurnal Chemistry in Education, ISSN NO 2250.

Ernest. 2001. Pengaruh Pengetahaun Subjektif Matematika. Jakarta : Universitas Terbuka.

Hapsari. 2010. Model-model Pembelajaran. Jakarta : Gramedia Pustaka.

Karfi. 2002. Perencanaan Berdasarkan Pendekatan Sistem. Jakarta : Bumi Aksara.

Lapono. 2008. Perkembangan Belajar Peserta Didik. Jakarta: Bumi Aksara.

Ma'sum. 2012. Memahami Penelitian Kualitatif. Bandung: Alfabeta.

Muslich. 2007. Sertifikasi Guru Menuju Profesionalisme Pendidik, Jakarta : Bumi Aksara.

Nur Chasanah. 2015. Pengaruh Peningkatan Matematika Melalui Pendekatan Konstruktivisme. Jurnal Chemistry in Education, ISSN NO 3320 .

Sagala, Syaiful. 2007. Konsep dan Makna Pembelajaran. Bandung: ALFABETA.
Sanjaya, Wina. 2011. Pembelajaran dalam implementasi KBK, Jakarta : Prenada Media Group.

Setiadi. 2011. Pengantar Sosiologi. Jakarta: Kencana.

Sumarni. 2016. Penerapan Metode Eksperimen Berpendekatan Inkuiri untuk Meningkatkan Pemahaman Konsep dan Sikap Ilmiah. Jurnal Chemistry in Education, ISSN NO 2252-6609. Diunduh pada 20 April 2019 dari http:/ / journal.unnes.ac.id/ sju/ index.php/ chemined.

Sumarmo. 2010. Berfikir dan Disposisi Matematika. Yogyakarta: Mitra Pustaka.

Suratno. 2008. Macam-macam Sumber Belajar . Jakarta : Gramedia Pustaka.

Thobroni. 2015. Hasil Belajar. Jakarta: Bumi Aksara.

Trianto. 2007. Model-model Pembelajaran iInovatif berorientasi kontruktivistik. Jakarta. Prestasi Pustaka. 